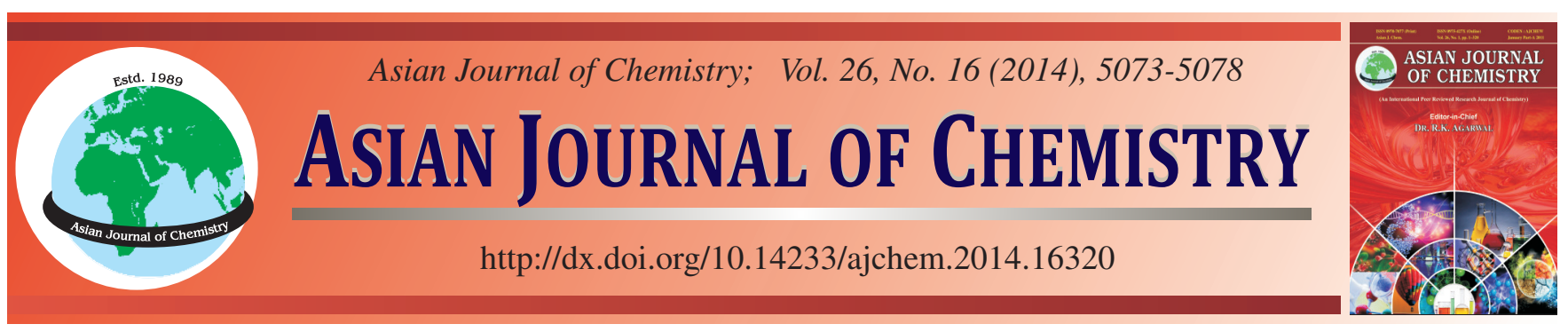

\title{
Semi-Empirical Computation on Mechanism of Imidazolines and Benzimidazoles Synthesis and Their QSAR Studies
}

\author{
Swapnali Hazarika ${ }^{1, *}$, Dilip Konwar ${ }^{2}$ and Manas Jyoti Bora ${ }^{2}$
}

${ }^{1}$ Chemical Engineering Division, CSIR-North East Institute of Science and Technology, Jorhat-785 006, India

${ }^{2}$ Synthetic Organic Chemistry Division, CSIR-North East Institute of Science and Technology, Jorhat-785 006, India

*Corresponding author: E-mail: shrrljt@yahoo.com

\begin{abstract}
A green, mild and anaerobic synthesis of imidazolines and benzimidazoles from aldehydes and diamines using $\mathrm{I}_{2} / \mathrm{KI} / \mathrm{K}_{2} \mathrm{CO}_{3} / \mathrm{H}_{2} \mathrm{O}$ system has been investigated by semi-empirical methods. The observed efficient direction of the above synthesis has been modeled from a comparison of the energies of four possible transition states arising from mono and di additions of iodines in the configured molecules. In the reaction $\mathrm{I}_{1} \mathrm{~B}$ is the most favorable transition state [TS] which is shown to be $20 \mathrm{Kcal} / \mathrm{mol}$ by $\mathrm{PM}_{3}$ analyses. The resulting trends of relative transition states energies are in excellent agreement with the experimental observations. Also, the bond order, bond length, heat of formation is in good agreement to the formation of product $\mathbf{B}$. In order to establish the suitable mechanism of the reaction a quantitative structure activity relationship analysis has been made using hydrophobicity as the molecular descriptor. In this analysis the values of refractivity, polarizability, hydration energy, electron affinity, ionization potential and dipole moment of the compounds have been correlated with their hydrophobicity which has been taken as the molecular property.
\end{abstract}

Keywords: Imidazoline, Benzimidazole, Water media, ab initio, Semi-empirical transition states, Hydrophobicity, QSAR.

\section{INTRODUCTION}

Imidazoline and benzimidazole derivatives are found in many biologically active compounds and they show biological activities in anti-ulcer, anti-tumor and anti-viral effects etc. Also, in organic synthesis, imidazoline units are also used as synthetic intermediates, chiral auxiliaries, chiral catalysts and ligands for asymmetric catalysis ${ }^{1}$. On the other hand, $I_{2}$ has been used extensively as a synthetic reagent due to its inherent properties of low toxicity, elecrophilicity and easy handling. Accordingly, we reported Bronsted acid catalyzed oxidation of alcohols to aldehydes and ketones in the presence of DMSO, where the catalyst HI was generated in a redox process of $\mathrm{N}_{2} \mathrm{H}_{4}$ and $\mathrm{I}_{2}{ }^{2}$. We also reported the use of $\mathrm{I}_{2}$ for the deprotection of keto and aldoximes/imines and oxidation of alcohols to aldehydes and ketones in water ${ }^{3,4}$.

Recently, a practical, inexpensive and green method for the synthesis of imidazolines and benzimidazoles in water using $\mathrm{I}_{2} /$ $\mathrm{KI} / \mathrm{K}_{2} \mathrm{CO}_{3} / \mathrm{H}_{2} \mathrm{O}$ system under anaerobic conditions is also reported in the literature ${ }^{1}$. In this communication, we report a validation of this proposal by quantum mechanical calculations. The QSAR analyses of the final products are also presented here.

\section{RESULTS AND DISCUSSION}

Energies: The synthesis of imidazolines goes via two steps in the reaction mixture. In the presence of $\mathrm{I}_{2} / \mathrm{KI} /$
$\mathrm{K}_{2} \mathrm{CO}_{3} / \mathrm{H}_{2} \mathrm{O}$ system intermediate " $\mathrm{A}$ " is first formed from aryl/acyl aldehyde and diamines and that is anaerobically oxidized to form intermediates $\mathrm{I}_{1}$ and $\mathrm{I}_{2}$ that may produce four compounds $\mathrm{B} \& \mathrm{C}$ and D \& E eliminating $\mathrm{HI}$ and $2 \mathrm{HI}$ respectively which are scavenged by the base in the reaction mixture Scheme-I (Table-1).

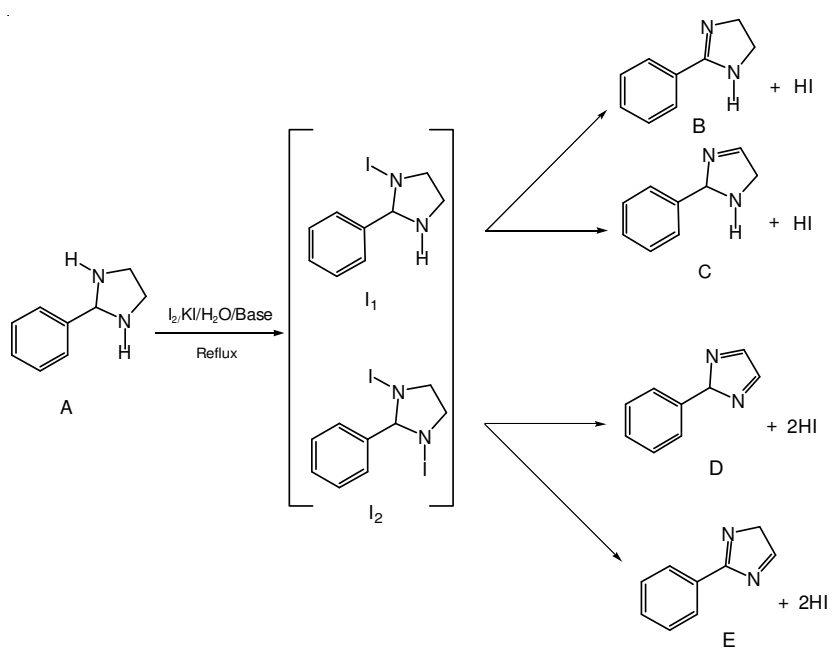

Scheme-I: Formation of possible products [B, C, D \& E] via intermediates $\mathrm{I}_{1} \& \mathrm{I}_{2}$ 
TABLE 1

SYNTHESIS OF IMIDAZOLINES AND BENZIMIDAZOLES FROM ALDEHYDES AND DIAMINES USING I//KI/K $\mathrm{K}_{2} \mathrm{CO}_{2} / \mathrm{H}_{2} \mathrm{O}$ SYSTEM IN WATER

\begin{tabular}{|c|c|c|c|c|c|c|}
\hline Entry & Aldehyde & Diamine & Product & Time (min) & Yield (\%) & Physical state * m.p. ${ }^{\circ} \mathrm{C}$ \\
\hline 1 & & & & 30 & 90 & $98-101$ \\
\hline 2 & & & & 30 & 95 & 140 \\
\hline 3 & & & & 30 & 95 & $129-231$ \\
\hline 4 & & & & 30 & 88 & 180 \\
\hline 5 & & & & 30 & 85 & $242-246$ \\
\hline 6 & & & & 35 & 80 & $105-108$ \\
\hline 7 & & & & 35 & 80 & 231 \\
\hline 8 & & & & 30 & 80 & $258-260$ \\
\hline 9 & & & & 45 & 75 & $102-106$ \\
\hline 10 & & & & 45 & 75 & 178 \\
\hline 11 & & & & 30 & 80 & oil \\
\hline 12 & & & & 30 & 85 & $104-106$ \\
\hline 13 & & & & 30 & 84 & 132 \\
\hline 14 & & $\mathrm{H}_{2} \mathrm{~N}$ & & 45 & 60 & 287 \\
\hline 15 & & $\mathrm{NH}_{2}$ & & 30 & 75 & $67-70$ \\
\hline 16 & & & & 45 & 75 & 295 \\
\hline 17 & & & & 45 & 78 & $223-226$ \\
\hline 18 & & & & 45 & 75 & 277 \\
\hline 19 & & & & 50 & 65 & $216-119$ \\
\hline 20 & & & & 50 & 65 & 330 \\
\hline
\end{tabular}


Fig. 1 presents the geometries of the four transition states i.e., $\mathrm{TsI}_{1} \mathrm{~B}, \mathrm{TsI}_{1} \mathrm{C}, \mathrm{TsI}_{2} \mathrm{D}$ and $\mathrm{TsI}_{2} \mathrm{E}$ corresponding to the four reaction channels as predicted. Table- 2 reports the total energies and heat of formation of the starting compound "A', intermediate $\mathrm{I}_{1}$ and $\mathrm{I}_{2}$ and the final products B, C, D and E in Kcal/ mol and a.u units. Both the AM1 and PM3 analyses of the products and intermediates show that the product "B' has the lowest heat of formation i.e., $41.0689499 \mathrm{Kcal} / \mathrm{mol}$ [AM1] and $57.1361720 \mathrm{Kcal} / \mathrm{mol}\left[\mathrm{PM}_{3}\right]$, respectively. Also, the intermediates $\mathrm{I}_{1}$ has lower heat of formation i.e., $45.4810 \mathrm{Kcal} / \mathrm{mol}$ then intermediate $I_{2}$, which clearly supports that the reaction goes via the intermediate $I_{1}$.

\section{$\mathbf{P M}_{3}$ values}

$$
\begin{aligned}
& \mathrm{a}_{1}=\text { activation energy }=\mathrm{I}_{1} \mathrm{~B}-\mathrm{I}_{1}=19.70 \mathrm{Kcal} / \mathrm{mol} \\
& \mathrm{a}_{2}=\text { activation energy }=\mathrm{I}_{1} \mathrm{C}-\mathrm{I}_{1}=29.33 \mathrm{Kcal} / \mathrm{mol} \\
& \mathrm{a}_{3}=\text { activation energy }=\mathrm{I}_{2} \mathrm{D}-\mathrm{I}_{2}=29.83 \mathrm{Kcal} / \mathrm{mol} \\
& \mathrm{a}_{4}=\text { activation energy }=\mathrm{I}_{2} \mathrm{E}-\mathrm{I}_{2}=57.25 \mathrm{Kcal} / \mathrm{mol}
\end{aligned}
$$

$\mathrm{TsI}_{1} \mathrm{~B} ; \mathrm{TsI}_{1} \mathrm{C} ; \mathrm{TsI}_{2} \mathrm{D} \& \mathrm{TsI}_{2} \mathrm{E}=$ Transition state energies [Ts] of the respective reactions in $\mathrm{Kcal} / \mathrm{mol}$

\section{$\mathbf{A M}_{1}$ values}

$$
\begin{aligned}
& \mathrm{a}_{1}=\text { activation energy }=\mathrm{I}_{1} \mathrm{~B}-\mathrm{I}_{1}=-15.79 \mathrm{Kcal} / \mathrm{mol} \\
& \mathrm{a}_{2}=\text { activation energy }=\mathrm{I}_{1} \mathrm{C}-\mathrm{I}_{1}=-6.13 \mathrm{Kcal} / \mathrm{mol} \\
& \mathrm{a}_{3}=\text { activation energy }=\mathrm{I}_{2} \mathrm{D}-\mathrm{I}_{2}=-9.74 \mathrm{Kcal} / \mathrm{mol} \\
& \mathrm{a}_{4}=\text { activation energy }=\mathrm{I}_{2} \mathrm{E}-\mathrm{I}_{2}=-3.87 \mathrm{Kcal} / \mathrm{mol}
\end{aligned}
$$

$\mathrm{TsI}_{1} \mathrm{~B} ; \mathrm{TsI}_{1} \mathrm{C} ; \mathrm{TsI}_{2} \mathrm{D} \& \mathrm{TsI}_{2} \mathrm{E}=$ transition state energies [Ts] of the respective reactions in $\mathrm{Kcal} / \mathrm{mol}$

The activation energy among the four reactive channels ie $\mathrm{TsI}_{1} \mathrm{~B}, \mathrm{TsI}_{1} \mathrm{C}, \mathrm{TsI}_{2} \mathrm{D} \& \mathrm{TsI}_{2} \mathrm{E}$, the transition state energy or the activation energy for $\mathrm{TsI}_{1} \mathrm{~B}$ is the lowest ie $20 \mathrm{Kcal} / \mathrm{mol}$ that clearly shows the formation " $\mathrm{B}$ ' is the most favored channel and that was experimentally found ${ }^{1}$. The value of the imaginary frequency for the $\mathrm{TsI}_{1} \mathrm{~B}$ is $-168.74 \mathrm{Kcal} / \mathrm{mol} \mathrm{A}^{2}$.

Geometrical parameters and analyses of frequencies: Table-3 refers the $\mathrm{PM}_{3}$ analyses of starting compound "A', transition states \& products A, B, C, \& D.
The geometries of the transition states corresponding to the four reactive channels $\mathrm{TsI}_{1} \mathrm{~B}, \mathrm{TsI}_{1} \mathrm{C}, \mathrm{TsI}_{2} \mathrm{D}$ and $\mathrm{TsI}_{2} \mathrm{E}$ are displayed in Figs. 1 and 2 represents the bond lengths of the four reaction channels in their transition states. Figs. 3 and 4 shows the bond orders of four reaction channel transition states.

Table-4 refers the bond Lengths of the transition states $\mathrm{I}_{1}-\mathrm{B}, \mathrm{I}_{1}-\mathrm{C}, \mathrm{I}_{2}-\mathrm{D} \& \mathrm{I}_{2}$-E in $\AA$. The bond length of $7 \mathrm{C}-8 \mathrm{~N}$ is 1.3544 $\AA$, the shortest bond length in $\mathrm{I}_{1}-\mathrm{B}$ among the other three reaction channels indicating the strongest bond, but the bond length of 7C-11N i.e., $1.4291 \AA$ is little longer then 7C-8N which indicates a new bond could be formed. Also, the bond

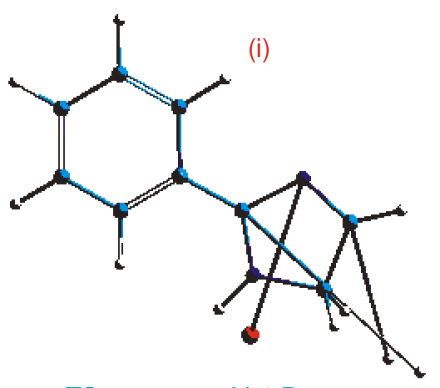

TS structure of $\mathrm{I}-1 \mathrm{~B}$

\begin{tabular}{|c|c|c|c|c|c|}
\hline \multicolumn{6}{|c|}{$\begin{array}{c}\text { TABLE-2 } \\
\text { AM1 AND PM3 ANALYSES OF REACTANT, INTERMEDIATE AND PRODUCT }\end{array}$} \\
\hline \multicolumn{3}{|r|}{ AM1 } & \multicolumn{3}{|c|}{ PM3 } \\
\hline Sl. No. & Compds. & $\begin{array}{c}\text { Total energy } \\
(\mathrm{K} \mathrm{Cal} / \mathrm{mol}) /[\mathrm{a} . \mathrm{u}] \\
\end{array}$ & $\begin{array}{l}\text { Heat of formation } \\
(\mathrm{K} \mathrm{Cal} / \mathrm{mol})\end{array}$ & $\begin{array}{c}\text { Total energy } \\
(\mathrm{K} \mathrm{Cal} / \mathrm{mol}) /[\mathrm{a} . \mathrm{u}]\end{array}$ & $\begin{array}{l}\text { Heat of formation } \\
(\mathrm{K} \mathrm{Cal} / \mathrm{mol})\end{array}$ \\
\hline 1 & A & $-36333.2589209 /-[57.899577601]$ & 28.8406931 & $-9911.5934709 /[-63.601902830]$ & 41.9801611 \\
\hline 2 & B & $-35613.8737581 /-[56.753187261]$ & 41.0689499 & $-39266.627148 /[-62.574104092]$ & 57.1361720 \\
\hline 3 & $\mathrm{C}$ & $-35605.4763130 /-[56.739805348]$ & 49.4663950 & $-39256.852882 /[-62.558528119]$ & 66.9104373 \\
\hline 4 & $\mathrm{D}$ & $-34874.6028103 /-55.575107538$ & 73.1829917 & $-38598.774390 /[-61.509834227]$ & 95.1786175 \\
\hline 5 & $\mathrm{E}$ & $-34880.9299941 /-[55.585190346]$ & 66.8558079 & $-38605.420373 /[-61.520425064]$ & 88.5326341 \\
\hline 6 & $\mathrm{I}_{1}$ & $-42637.4123686 /-[67.945685014]$ & 45.4810684 & $-47582.710339 /[-75.826361621]$ & 80.5058404 \\
\hline 7 & $\mathrm{I}_{2}$ & $-48940.5366016 /-[77.990152301]$ & 63.1506584 & $-55253.129258 /[-88.049708181]$ & 119.7294691 \\
\hline
\end{tabular}

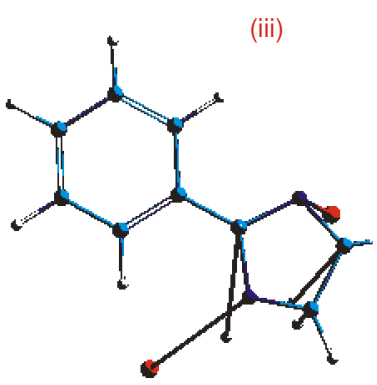

TS structure of I-2 B

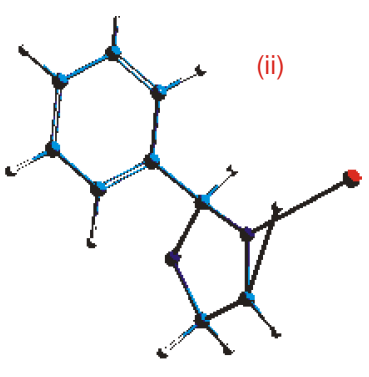

TS structure of $\mathrm{I}-1 \mathrm{C}$

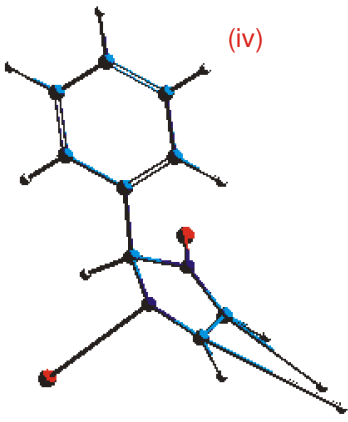

TS structure of I-2 E
Fig. 1. Transition states structures for four reactive channels

TABLE-3

TOTAL ENERGY OF THE INTERMEDIATES $\left[\mathrm{I}_{1}, \& \mathrm{I}_{2}\right]$ AND TRANSITION STATES OF THE FOUR REACTION CHANNELS ${ }^{4}$

\begin{tabular}{ccccc}
\hline S. No. & Compounds & $\begin{array}{c}\text { Total energy [Kcal/mol] } \\
\mathrm{PM}_{3} / \mathrm{AM}_{1}\end{array}$ & $\begin{array}{c}\text { Total energy [a.u.] } \\
\text { PM }_{3} / \mathrm{AM}_{1}\end{array}$ & $\begin{array}{c}\text { Heat of Formation [kcal/mol] } \\
\text { PM }_{3} / \mathrm{AM}_{1}\end{array}$ \\
\hline 1 & $\mathrm{I}_{1}$ & $-42637.4123686 /-47582.7103396$ & $-67.945685014 /-75.826361621$ & $45.4810684 / 80.5058404$ \\
2 & $\mathrm{I}_{2}$ & $-48940.5366016 /-55253.1292589$ & $-77.990152301 /-88.049708181$ & $63.1506584 / 119.7294691$ \\
3 & $\mathrm{Ts} \mathrm{I}_{1}-\mathrm{B}$ & $-42617.6914884 /-47598.5039100$ & $-67.945362189 /-75.853281120$ & $45.6836478 / 63.6132624$ \\
4 & $\mathrm{Ts} \mathrm{I}_{1}-\mathrm{C}$ & $-42608.0801666 /-47588.8440000$ & $-67.898942108 /-75.826213375$ & $74.8132704 / 80.5988676$ \\
5 & $\mathrm{Ts} \mathrm{I}_{2}-\mathrm{D}$ & $-48910.7089119 /-55262.8867000$ & $-77.942619801 /-88.066137003$ & $92.9783481 / 109.4200219$ \\
6 & $\mathrm{Ts} \mathrm{I}_{2}-\mathrm{E}$ & $-48881.2866739 /-55257.000000$ & $-77.895733416 /-88.076512374$ & $122.4005861 / 102.9092483$ \\
\hline
\end{tabular}




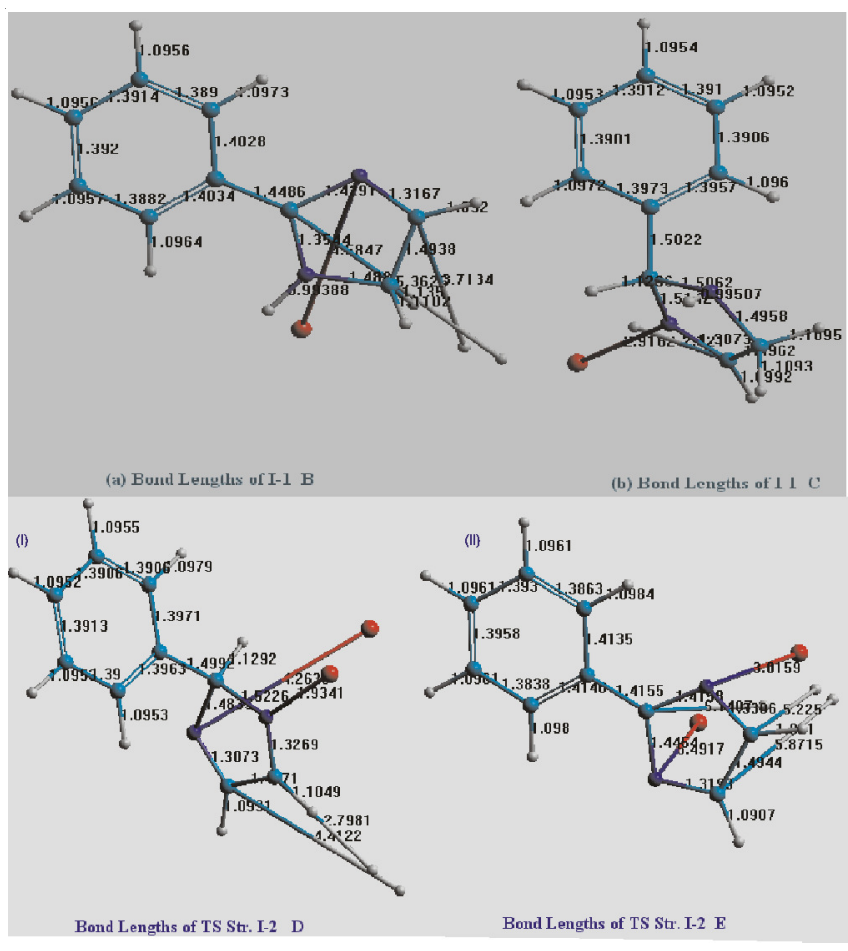

Fig. 2. Bond Lengths of transition states of B, C, D \& E

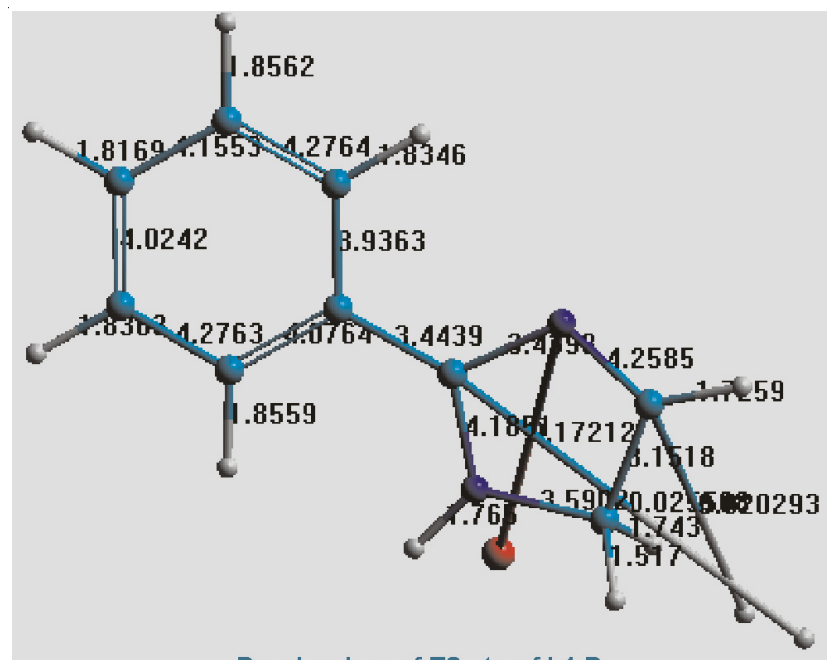

Bond orders of TS str. of I-1 B

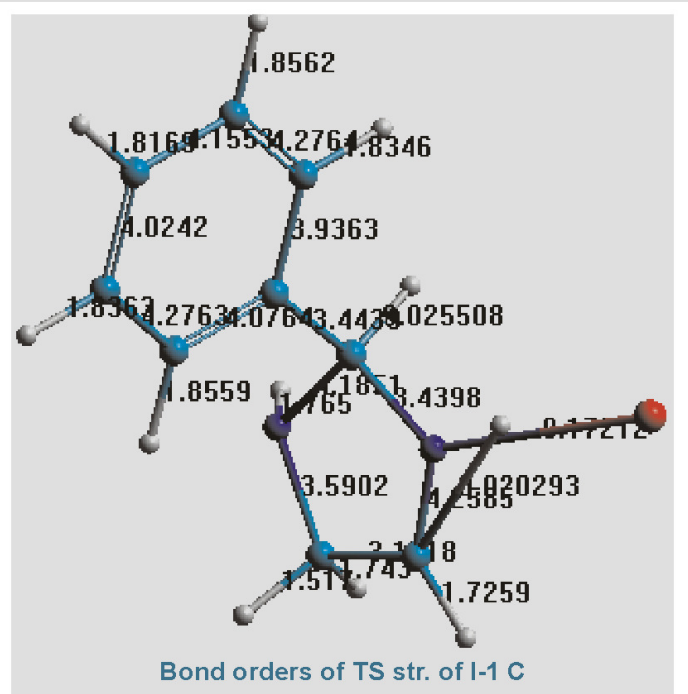

Fig. 3. Bond Orders of transition states of B \& C

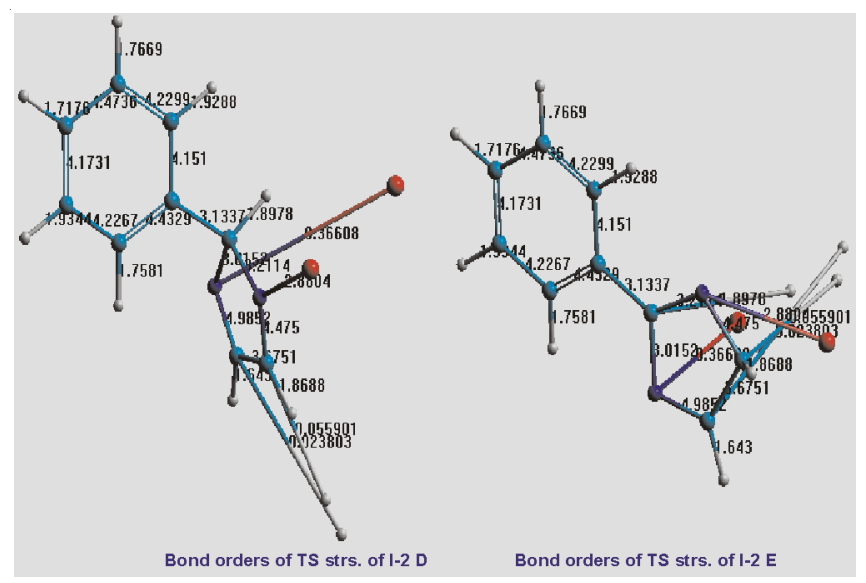

Fig. 4. Bond orders of transition states of D and E

length of $1_{1} \mathrm{~N}-1_{3} \mathrm{I}, 4.5847$ which is longest among other reaction channels that can be easily eliminated to form product "B". Which is experimentally correct. Among the two reactive channels $\mathrm{I}_{1}-\mathrm{B} \& \mathrm{I}_{1}-\mathrm{C}$; $\mathrm{I}_{1}-\mathrm{B}$ is longer i.e., $5.3626 \AA$ or by 3.4523 $\AA$ in $7 \mathrm{C}-19 \mathrm{H}$ indicates the $\mathrm{C} 19$ proton can form easily $\mathrm{HI}$ in the reaction mixture. Though in the case of $\mathrm{I}_{2}-\mathrm{D} \& \mathrm{I}_{2}$-E reaction channels 7C-19 H proton in $\mathrm{I}_{2}$-E shows higher value i.e., 6.1406 $\AA$ due to presence of two iodine atoms in the intermediate stage, but the heat of formation of the systems is much more higher then the heat of formation of $\mathrm{I}_{1}-\mathrm{B}$, therefore it can be neglected.

Bond order analyses: The extent of bond formation or bond breaking along a reaction path way is provided by the concept of bond order (BO). This theoretical tool has been used to study the molecular mechanism of chemical reactions [r]. The bond orders of the TSs of four reaction channels implemented in Hyper chem. 7.5. The results are included in Table-5.

Table- 6 refers the bond orders of transition states of four reactive channels $\left[\mathrm{I}_{1}-\mathrm{B}, \mathrm{I}_{1}-\mathrm{C}, \mathrm{I}_{2}-\mathrm{D} \& \mathrm{I}_{2}-\mathrm{E}\right]$. In the first two reaction channels $\mathrm{I}_{1}-\mathrm{B} \& \mathrm{I}_{1}-\mathrm{C}$, the bond orders of $7 \mathrm{C}-11 \mathrm{~N}$ are 3.4426 $\AA \& 2.9335 \AA$ that are less in bond orders then $7 \mathrm{C}-8 \mathrm{~N}, 4.182$ \& 2.9434 which clearly indicates $7 \mathrm{C}-8 \mathrm{~N}$ bond comparatively stronger then $7 \mathrm{C}-11 \mathrm{~N}$. Also, the bond orders of $7 \mathrm{C}-19 \mathrm{H}$ bond are $0.02545 \& 1.9103$, respectively which show that the $7 \mathrm{C}$ $19 \mathrm{H}$ in the reaction channel $\mathrm{I}_{1}-\mathrm{B}$ is comparatively weak and lible to break easily to give product "B' which was eperimentally found. Also, the bond orders of C7-N8 in $\mathrm{I}_{1}-\mathrm{B}$ is 4.182, the highest among the four reaction channels which clearly indicates that there is no breaking of that bond or form a $\mathrm{C}=\mathrm{N}$ bond after oxidation by the system ie $\mathrm{I}_{2} / \mathrm{KI} / \mathrm{K}_{2} \mathrm{CO}_{3} / \mathrm{H}_{2} \mathrm{O}$.

Also, the bond orders of $7 \mathrm{C}-19 \mathrm{H}$ bond $\mathrm{I}_{2}-\mathrm{D} \& \mathrm{I}_{2}-\mathrm{E}$ are $1.8724 \& 0.0013305$, respectively which show that the 7C-19 $\mathrm{H}$ in the reaction channel $\mathrm{I}_{2}-\mathrm{E}$ is weak and lible to break easily to give product "E'.

From the above findings it is stated that the reaction mechanism as put forwarded for the product formation "B' in the previous report is validated quantum mechanically and is shown in Fig. 5.

Quantitative structure activity relationship [QSAR] analyses of imidazolines and benzimidazoles [1-20]: Quantitative structure activity relationship technique is indispensable in all research as it depends on the three dimensional arrangement of the atoms in a molecule. QSAR is a mathematical 


\begin{tabular}{|c|c|c|c|c|c|c|}
\hline \multicolumn{7}{|c|}{ PM3 ANALYSES OF STARTING COMPOUND “ } \\
\hline \multicolumn{2}{|c|}{ Angles } & \multicolumn{2}{|c|}{ Starting compound $(\AA)$} & \multicolumn{2}{|c|}{ I-1 B [Ts $]^{0}$} & $\mathrm{I}-1 \mathrm{C}[\mathrm{Ts}]$ \\
\hline C7-N8- & & \multicolumn{2}{|c|}{108.537} & \multicolumn{2}{|c|}{109.956} & 107.625 \\
\hline N8-C7- & N11 & \multicolumn{2}{|c|}{107.14} & \multicolumn{2}{|c|}{108.477} & 104.144 \\
\hline C7-N11- & $\mathrm{C} 10$ & \multicolumn{2}{|c|}{108.415} & \multicolumn{2}{|c|}{109.68} & 111.20 \\
\hline \multicolumn{7}{|c|}{$\begin{array}{c}\text { TABLE-5 } \\
\text { BOND LENGTHS OF THE TRANSITION } \\
\text { STATES } \mathrm{I}_{1}-\mathrm{B}, \mathrm{I}_{1}-\mathrm{C}, \mathrm{I}_{2}-\mathrm{D} \& \mathrm{I}_{2}-\mathrm{E} \text { IN ARMSTRONG }\end{array}$} \\
\hline Bonds & $\mathrm{I}_{1}-\mathrm{B}$ & $\mathrm{I}_{1}-\mathrm{C}$ & $\mathrm{I}_{2}-\mathrm{D}$ & & & $\mathrm{I}_{2}-\mathrm{E}$ \\
\hline $7 \mathrm{C}-8 \mathrm{~N}$ & 1.3544 & 1.5062 & 1.483 & & & 1.4455 \\
\hline $7 \mathrm{C}-11 \mathrm{~N}$ & 1.4291 & 1.5142 & 1.522 & & & 1.4158 \\
\hline $9 \mathrm{C}-8 \mathrm{~N}$ & 1.488 & & 1.30 & & & 1.3194 \\
\hline $9 \mathrm{C}-10 \mathrm{C}$ & 1.4938 & 1.4962 & 1.46 & & & 1.4944 \\
\hline $10 \mathrm{C}-11 \mathrm{~N}$ & 1.3167 & 1.3073 & 1.326 & & & 1.3306 \\
\hline $11 \mathrm{~N}-13 \mathrm{I}$ & 4.5847 & 2.9162 & 1.934 & & & 3.0159 \\
\hline $8 \mathrm{~N}-12 \mathrm{H}$ & 0.99388 & 0.99507 & $4.2636(\mathrm{~N}$ & $\left.-I_{12}\right)$ & 6.49 & $17\left(\mathrm{~N}_{8}-\mathrm{I}_{12}\right)$ \\
\hline $9 \mathrm{C}-20 \mathrm{H}$ & 1.135 & 1.1093 & 4.412 & & & 5.8715 \\
\hline $9 \mathrm{C}-21 \mathrm{H}$ & 1.1102 & 1.1095 & 1.093 & & & 1.0907 \\
\hline $10 \mathrm{C}-22 \mathrm{H}$ & 3.7134 & 2.121 & 2.798 & & & 5.225 \\
\hline $10 \mathrm{C}-23 \mathrm{H}$ & 1.092 & 1.0992 & 1.104 & & & 1.091 \\
\hline $7 \mathrm{C}-19 \mathrm{H}$ & 5.3626 & 1.1236 & 1.129 & & & 6.1406 \\
\hline
\end{tabular}

TABLE-6

BOND ORDERS OF TRANSITION STATES OF FOUR REACTIVE CHANNELS [ $\mathrm{I}_{1}-\mathrm{B}, \mathrm{I}_{1}-\mathrm{C}, \mathrm{I}_{2}-\mathrm{D} \& \mathrm{I}_{2}$-E]

\begin{tabular}{ccccc}
\hline Bonds & $\mathrm{I}_{1}-\mathrm{B}$ & $\mathrm{I}_{1}-\mathrm{C}$ & $\mathrm{I}_{2}-\mathrm{D}$ & $\mathrm{I}_{2}-\mathrm{E}$ \\
\hline $7 \mathrm{C}-8 \mathrm{~N}$ & 4.182 & 2.9434 & 3.1488 & 2.7544 \\
$7 \mathrm{C}-11 \mathrm{~N}$ & 3.4426 & 2.9335 & 3.089 & 3.802 \\
$9 \mathrm{C}-8 \mathrm{~N}$ & 3.5903 & 3.8493 & 4.9543 & 4.3964 \\
$9 \mathrm{C}-10 \mathrm{C}$ & 3.1526 & 3.8177 & 3.8186 & 3.6333 \\
$10 \mathrm{C}-11 \mathrm{~N}$ & 4.257 & 4.6291 & 4.1359 & 4.5001 \\
$11 \mathrm{~N}-13 \mathrm{I}$ & 0.17248 & 1.0762 & 2.8089 & 0.37588 \\
$8 \mathrm{~N}-12 \mathrm{H}$ & 1.7654 & 1.7295 & $0.3695\left(\mathrm{~N}_{8}-\mathrm{I}_{12}\right)$ & $0.0020\left(\mathrm{~N}_{8}-\mathrm{I}_{12}\right)$ \\
$9 \mathrm{C}-20 \mathrm{H}$ & 1.7425 & 1.9407 & 0.024908 & 0.0042434 \\
$9 \mathrm{C}-21 \mathrm{H}$ & 1.517 & 1.934 & 1.4697 & 1.5966 \\
$10 \mathrm{C}-22 \mathrm{H}$ & 0.020419 & 0.0674 & 0.055389 & 0.0039567 \\
$10 \mathrm{C}-23 \mathrm{H}$ & 1.7259 & 1.8134 & 1.84 & 1.692 \\
$7 \mathrm{C}-19 \mathrm{H}$ & 0.02545 & 1.9103 & 1.8724 & 0.0013305 \\
\hline
\end{tabular}

TABLE-4

'A', TRANSITION STATES \& PRODUCTS A, B, C, \& D

\begin{tabular}{cccccc}
${\text { I-2D [TS }]^{0}}$ & $\mathrm{I}^{2} \mathrm{E}[\mathrm{TS}]^{0}$ & $\mathrm{~B}^{0}$ & $\mathrm{C}^{0}$ & $\mathrm{D}^{0}$ & $\mathrm{E}^{0}$ \\
\hline 110.391 & 107.304 & 107.063 & 107.011 & 109.041 & 108.195 \\
101.751 & 108.395 & 111.996 & 104.982 & 103.132 & 110.383 \\
109.293 & 107.881 & 111.209 & 111.052 & 108.987 & 109.050 \\
\hline
\end{tabular}

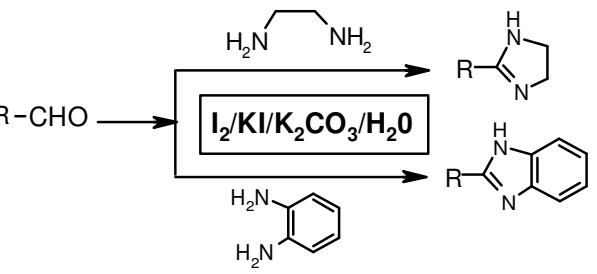

$\mathrm{R}=$ alkyl, aryl, $\mathrm{CHO}$

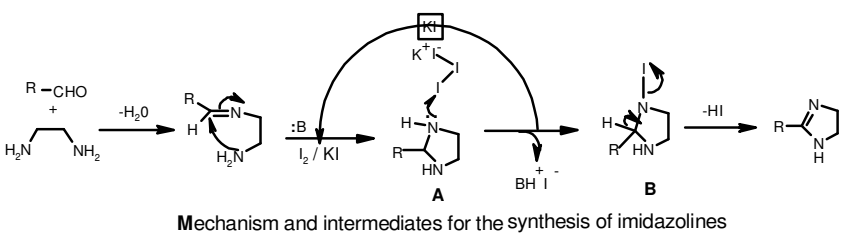

Fig. 5. Mechanism and intermediates for the synthesis of imidazolines

model and it relates the chemical structure and physical property of a compound in a quantitative manner. In our present work we have taken 20 compounds given in Table-7 in the modeling study of octanol water partition co-efficient $(\log \mathrm{P})$. The values of $\log \mathrm{P}$ were determined by using Hyperchem software.

We have selected different descriptors for QSAR study such as, the energy of highest occupied molecular orbital (EHOMO), energy of lowest unoccupied molecular orbital (ELUMO), etc. In addition, the molecular mechanics (MM) parameters such as molar refractivity (MR), van der Waals surface area (SA), hydrophobicity $(\log \mathrm{P})$ and molecular volume $(\mathrm{V})$ of the molecules were also selected. The values of surface area, volume, hydration energy, $\log$ P, refractivity,

TABLE-7

QSAR PROPERTIES OF THE COMPOUNDS

\begin{tabular}{ccccccccc}
\hline S. No. & Surface area & ${\text { Volume }\left(\AA^{3}\right)}^{3}$ & Hydration energy $(\mathrm{Kcal} / \mathrm{mol})$ & $\log$ P & Refractivity & Polarizibility & Mass $(\mathrm{amu})$ & Dipole $(\mathrm{D})$ \\
\hline 1 & 263.262 & 508.287 & -4.060 & 1.700 & 44.520 & 17.450 & 146.192 & 2.175 \\
2 & 322.138 & 584.489 & -5.679 & 1.448 & 50.983 & 19.922 & 176.218 & 1.112 \\
3 & 358.024 & 658.467 & -6.006 & 1.195 & 57.447 & 22.394 & 206.244 & 2.754 \\
4 & 306.531 & 560.191 & -2.852 & 2.167 & 49.561 & 19.285 & 160.219 & 1.203 \\
5 & 307.529 & 570.071 & -3.682 & 2.492 & 52.143 & 20.076 & 225.088 & 2.677 \\
6 & 319.132 & 590.96 & -3.215 & 2.736 & 54.130 & 21.306 & 215.082 & 2.079 \\
7 & 317.191 & 570.864 & -9.014 & -0.279 & 51.343 & 19.291 & 191.189 & 6.313 \\
8 & 366.021 & 640.991 & -2.445 & 1.965 & 58.949 & 22.471 & 189.260 & 2.207 \\
9 & 251.301 & 496.697 & -5.626 & 1.318 & 42.300 & 16.741 & 147.180 & 2.331 \\
10 & 253.647 & 484.560 & -4.811 & -0.452 & 45.955 & 16.972 & 152.214 & 3.005 \\
11 & 279.918 & 563.928 & -3.615 & 1.633 & 49.069 & 19.285 & 160.219 & 1.808 \\
12 & 411.340 & 639.591 & -5.253 & 1.380 & 55.533 & 21.757 & 190.245 & 2.065 \\
13 & 304.503 & 576.166 & -0.723 & 1.663 & 45.550 & 18.026 & 152.239 & 1.621 \\
14 & 239.091 & 480.031 & -5.504 & -0.331 & 37.846 & 17.804 & 138.172 & 2.513 \\
15 & 501.503 & 777.072 & 0.686 & 3.190 & 61.181 & 24.305 & 196.336 & 2.612 \\
16 & 302.142 & 620.572 & -7.555 & 3.334 & 60.282 & 23.440 & 194.236 & 3.182 \\
17 & 361.057 & 696.599 & -9.170 & 3.081 & 66.745 & 25.912 & 224.262 & 3.029 \\
18 & 345.334 & 672.255 & -6.351 & 3.801 & 65.323 & 25.275 & 208.263 & 1.492 \\
19 & 290.603 & 611.387 & -8.469 & 2.886 & 57.722 & 22.731 & 195.224 & 2.268 \\
20 & 292.022 & 596.385 & -8.329 & 1.181 & 61.716 & 22.962 & 200.258 & 3.579 \\
\hline
\end{tabular}




\begin{tabular}{cccccccc}
\hline \multicolumn{7}{c}{ TABLE-8 } \\
\multicolumn{7}{c}{ CALCULATED THERMODYNAMIC PARAMETERS OF THE COMPOUNDS } \\
\hline Structure & $\begin{array}{c}\text { Enthalpy } \\
(\text { Kcal/mol })\end{array}$ & $\begin{array}{c}\text { Entropy } \\
(\text { Kcal/mol//Kelvin })\end{array}$ & $\begin{array}{c}\text { Free energy } \\
(\text { Kcal/mol })\end{array}$ & $\begin{array}{c}\text { Heat capacity } \\
(\text { Kcal/mol/Kelvin })\end{array}$ & $\begin{array}{c}\text { Heat of formation } \\
(\text { Kcal/mol })\end{array}$ & $\begin{array}{c}\text { HOMO } \\
(\mathrm{eV})\end{array}$ & $\begin{array}{c}\text { LUMO } \\
(\mathrm{eV})\end{array}$ \\
\hline 1 & 5.79 & 89.62 & 78.64 & 35.47 & 41.28 & -9.05 & -0.32 \\
2 & 7.53 & 103.99 & 53.08 & 44.80 & 2.91 & -8.83 & -0.27 \\
3 & 8.17 & 108.97 & 54.55 & 48.75 & -3.89 & -8.78 & -0.23 \\
4 & 7.003 & 101.80 & 75.28 & 41.448 & 31.80 & -8.96 & -0.31 \\
5 & 6.72 & 99.80 & 84.24 & 39.56 & 49.16 & -9.18 & -0.59 \\
6 & 7.35 & 103.82 & 70.81 & 43.01 & 31.09 & -9.04 & -0.68 \\
7 & 7.44 & 105.51 & 82.49 & 43.82 & 33.01 & -9.57 & -1.48 \\
8 & 8.41 & 110.44 & 99.65 & 50.76 & 37.44 & -8.41 & -0.24 \\
9 & 5.72 & 89.31 & 87.57 & 34.73 & 48.35 & -9.32 & -0.64 \\
10 & 5.55 & 88.34 & 80.60 & 33.14 & 50.76 & -9.09 & -0.77 \\
11 & 6.59 & 96.39 & 84.26 & 40.38 & 39.16 & -9.27 & -0.51 \\
12 & 8.31 & 110.43 & 59.24 & 49.64 & 1.22 & -8.76 & 0.54 \\
13 & 6.52 & 94.52 & 56.29 & 40.79 & -7.68 & -9.16 & 0.86 \\
14 & 6.20 & 92.21 & 81.93 & 35.74 & 32.85 & -9.10 & -0.15 \\
15 & 11.34 & 139.72 & 53.77 & 63.15 & 35.31 & -9.21 & 0.79 \\
16 & 7.51 & 106.65 & 105.57 & 45.96 & 71.67 & -8.76 & -0.61 \\
17 & 9.25 & 121.61 & 79.87 & 55.24 & 33.34 & -8.59 & -0.55 \\
18 & 8.13 & 110.79 & 104.63 & 49.90 & 62.20 & -8.69 & -0.60 \\
19 & 7.42 & 104.55 & 118.03 & 45.15 & 81.73 & -8.82 & -0.80 \\
20 & 7.25 & 104.80 & 107.77 & 43.57 & 81.23 & -8.79 & -0.96 \\
\hline
\end{tabular}

polarizibility, mass and dipole moments of the compounds 1-20 [products] were given in Table-8. During the analysis Geometries of the compounds were optimized with Semi Empirical method PM3 using optimization algorithm polakribiere under RHF conditions.

From Table-7 it has been seen that greater aliphatic or etheral moiety has least value of heat of formation which is confirmed by comparing the values of compound $\mathbf{3 , 1 5}$ and 12. Small value of dipole moment is observed when methyl ether linkage is present in the compound. In case of benzofused compounds (entries 16-20) dipole moment increases but due to presence of methyl group (aliphatic character) dipole moment decreases appreciably. There is a good linear relationship between $\log \mathrm{P}$ and ionization potential and electron affinity as shown in Fig. 6. Other properties such as dipole moment, polarizability, molar refractivity and connectivity index have not good relationship with $\log$ P. However, effect of molecular structure of the compound on other properties can be analyzed by considering hydrophobicity as the molecular property.

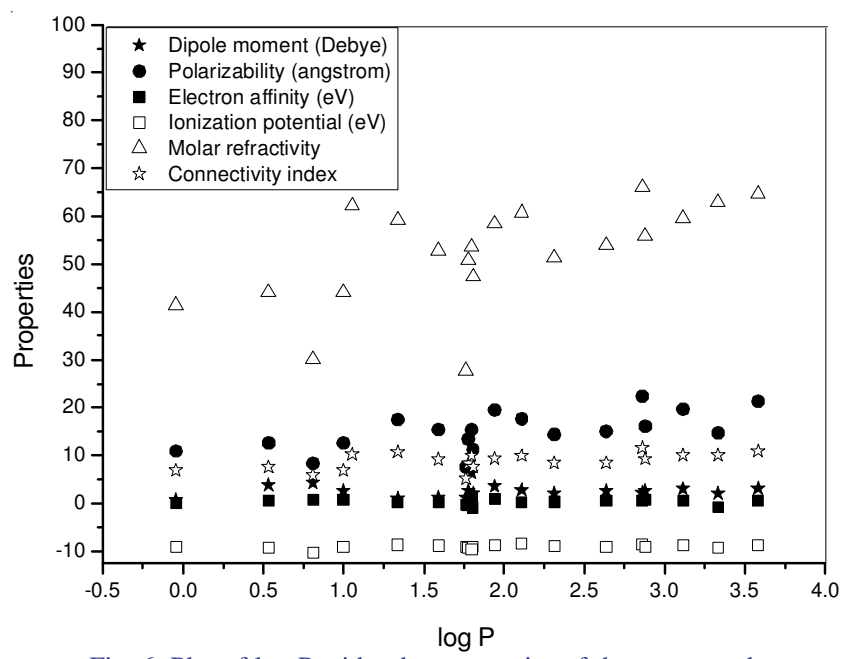

Fig. 6. Plot of $\log \mathrm{P}$ with other properties of the compounds
The values of thermodynamic parameters of the products were determined by using Scigress 4.2 software and are shown in Table-7. The positive values of heat of formation reflect an endothermic process whereas negative values of entropy implies an association process rather than dissociation. HOMO energy of the molecule associated with the electron donating ability of the molecule and LUMO energy indicates the electron accepting ability. Although, HOMO energy is associated with the electron donating ability of the molecule, high values of HOMO energy indicates a tendency of the molecule to donate electrons to appropriate acceptor molecules with low energy and empty molecular orbital.

\section{ACKNOWLEDGEMENTS}

The authors acknowledged Dr. R.C. Baruah, Director CSIR-NEIST, Jorhat, Assam.

\section{REFERENCES}

1. P. Gogoi and D. Konwar, Tetrahedron Lett., 47, 79 (2006).

2. P. Gogoi, G.K. Sarmah and D. Konwar, J. Org. Chem., 69, 5153 (2004).

3. P. Gogoi, P. Hazarika and D. Konwar, J. Org. Chem., 70, 1934 (2005).

4. M.G.B. Drew, L.M. Harwood, D.W. Price, M.S. Choi and G. Park, Tetrahedron Lett., 41, 5077 (2000). 